\title{
The health workforce crisis
}

\section{A crise da força de trabalho em saúde}

\author{
La crisis del personal sanitario
}

According to the World Health Report 1, stress and insecurity have increased among health workers worldwide due to the complex combination of old and new causes and problems. The implementation of new healthcare models, the introduction of new technologies, and changes in the epidemiological profile all have a direct impact on health workforce needs. Globalization, population aging, and new consumer expectations can also dramatically shift demands on the health workforce. As part of the global political economy, beginning in the 1990s there was a significant increase in the international migration of physicians and especially of nurses, seeking job opportunities and security in more dynamic labour markets.

Added to this context were the negative consequences of financial adjustment and reform programs supported by the International Monetary Fund (IMF) and World Bank in the 1980s, culminating with an important reduction in national capacities for spending in such crucial social areas as health and education. In addition, the emergence or reemergence of diseases with a major impact on the population, plus the acceleration of the HIV/AIDS epidemic during the same period, contributed greatly to the increasing demand for more health workers.

Although this set of problems is not exactly new, the context led to what has come to be
Mario Roberto Dal Poz 1

called the global health workforce crisis, characterized by an estimated global shortage of four million health professionals ${ }^{1}$ and regional, national, and sub-national inequalities in the distribution of (and access to) the health workforce. This inequality in distribution affects nearly all countries, including Brazil, with a shortage of qualified health personnel especially in rural, peripheral-urban, or difficult-to-access areas.

Imbalances in the composition and distribution of health teams further complicate current health problems. In many countries, the professional training of a limited number of health workers, although costly, is not necessarily adequate for local health needs. There is also a frequent shortage of qualified personnel in public health and policymaking and management. Many health workers are subject to adverse work environments - humiliating wages, lack of support from administrators, insufficient social recognition, and weak career development 2 .

The poor distribution characterized by urban concentration and rural shortages is not the privilege of any particular country, since nearly all nations suffer from these imbalances, including Brazil. Scheffer et al. ${ }^{3}$ (p. 13) analyze medical demographics in Brazil, calling attention to "the worsening inequalities in health workforce distribution and even the total absence of health workers in some local circumstances". A study by 
the Brazilian Ministry of Health on the need for medical specialists showed regional inequalities in their supply, undersupply/shortage of some specialties, new needs resulting from the social, demographic, and epidemiological transitions, difficulties in the recruitment of medical specialists, and inadequate distribution of medical residency openings in the country ${ }^{4}$. The difference between physician supply and demand has increased in the last decade, heavily fueling this labour market, contrary to the situation with nurses and dentists 5. Brazil has an average of 1.8 physicians per 1,000 inhabitants, more than most Latin American countries, although fewer than (although comparable to) many developed countries, including the United States (2.5). However, a study aimed at constructing an index on physician shortage in Brazil showed that in 2010 there were 1,304 municipalities (counties) with a shortage of physicians 6 .

And the health workforce crisis has the potential to become worse in the coming years. The demand for health workers has increased markedly in all countries, rich or poor. The wealthiest countries are glimpsing a future with a low fertility rate and marked population aging, which will cause an increase in the number of chronic and degenerative diseases, with a resulting higher demand for healthcare. Technological advances and income growth will require a more specialized health workforce, even as basic healthcare needs increase due to the decreasing capacity, availability, or willingness of families to care for the elderly. Without massive investment in training, these growing inequalities will produce even greater pressure for emigration of health professionals from poorer regions.

In middle and low-income countries, large contingents of young people will join an increasingly aged population in a rapid process of urbanization. Many of these countries are still grappling with unresolved infectious disease agendas, complicated by the rapid emergence of chronic diseases and the magnitude of the HIV/ AIDS epidemic. The availability of efficacious vaccines and drugs to deal with these health threats pose enormous practical and ethical imperatives for an effective response. The gap is widening between what could be done and what is actually being done in practice. The success in narrowing this gap will be determined to a major extent by the adequate development of the health workforce in order to make health systems more effective.

The street protests in Brazil this June, demanding better health services, and the "Health +10 Movement" certainly created a timely context for the debate on middle and long-term op- tions to deal with the crisis in the country's health system. In the short term, the measures adopted by the Ministry of Health, such as the Program for Valorization of Basic Healthcare Professionals (PROVAB) and the "More Doctors" program have the merit of dealing with the acute shortage in certain regions of the country. However, such programs have left many problems behind to the extent that they: only focus on one professional group (physicians), clash with professional medical associations, and overlook the linkage between different levels of care and especially the severe under-financing of the Unified National Health System (SUS) at all levels.

In Brazil, previous attempts to retain health professionals in underserved areas have failed to prove sustainable over time, although they have been more or less successful in the short term. Examples include the Program for the Interiorization of Health and Sanitation Actions (PIASS), the implementation of undergraduate internships in rural areas, and more recently the now-defunct Program for the Interiorization of Health Workers (PITS) ${ }^{7}$. The Family Health Strategy, although not specifically designed with this objective, perhaps constitutes the most successful example of expansion of physician coverage in Brazilian territory.

According to the World Health Organization (WHO), the most important aspect is that the formulation of national programs to improve health worker recruitment and retention in remote and rural areas should include interconnected interventions linked to the National Health Plan. This recommendation is part of a set of global recommendations for retaining health workers in such areas, elaborated by the WHO on the basis of scientific evidence and technical consensus by hundreds of specialists 8 .

As the WHO recommends, "The choice of interventions should be informed by an in-depth understanding of the health workforce." 8 This requires analyzing the labour market in health and the factors influencing health workers' decisions not only when moving to rural and remote areas, but also when staying there versus abandoning them. Without this knowledge, the choices and interventions become unsustainable and are generally rejected by health workers. According to the $\mathrm{WHO}$, in order to be successful, a program aimed at improving the recruitment and retention of health workers in remote or rural areas should include four types of interconnected interventions: training, regulation, incentives, and professional and personal support 8 .

According to Araújo \& Maeda9,"There is an emerging consensus that policies for recruitment and retention in rural and remote areas need to 
address two critical issues: i) to be effective, interventions need to be implemented in bundles, combining different packages of interventions according to the variety of factors influencing the health worker's decision to work in rural or remote areas; ii) to match the interventions with health worker's preferences and expectations, since the health worker's employment decisions are a function of these preferences."

To answer these questions and support the elaboration and implementation of programs for recruitment and retention of health workers in developing countries, the approach known as Discrete Choice Experiments (DCE) has been increasingly applied with the support of the World Bank, in partnership with WHO and Capacity Plus/USAID, and studies of this type have begun to be applied in Brazil 6 .

The evaluation of these and other experiments, including an articulated research agenda, can allow the development of policy and program options to deal with a crisis that has curtailed the capacity of national health systems to improve the health of their populations 10 .

\section{References}

1. World Health Organization. World Health Report 2006: working together for health. Geneva: World Health Organization; 2006.

2. Dussault G, Dubois CA. Human resources for health policies: a critical component in health policies. Hum Resour Health 2003; 1:1.

3. Scheffer M, Biancarelli M, Cassenote A, coordenadores. Demografia Médica no Brasil: dados gerais e descrições de desigualdades. v. 1. São Paulo: Conselho Regional de Medicina do Estado de São Paulo/Conselho Federal de Medicina; 2011.

4. Comissão Interministerial de Gestão da Educação na Saúde. Avaliação das necessidades de médicos especialistas. http://portal.mec.gov. br/index.php?option $=$ com_docman\&task $=$ doc download\&gid=1509\&Itemid=95 (accessed on 20/ Aug/2013).

5. Dal Poz MR, Girardi SN, Pierantoni CR. Formação, regulação profissional e mercado de trabalho em saúde In: Fundação Oswaldo Cruz, organizador. A saúde no Brasil em 2030: diretrizes para a prospecção estratégica do sistema de saúde brasileiro. Rio de Janeiro: Fundação Oswaldo Cruz/Instituto de Pesquisa Econômica Aplicada/Ministério da Saúde/Secretaria de Assuntos Estratégicos da Presidência da República; 2012. p. 157-68.

6. Girardi SN, coordenador. Estudo de preferência declarada sobre atributos relevantes para a atração e fixação de médicos no Estado de Minas Gerais: relatório final de atividades. http://epsm.nes con.medicina.ufmg.br/epsm/ (accessed on 19/ Aug/2013).
7. Maciel Filho R, Branco MAF. Rumo ao Interior: médicos, saúde da família e mercado de trabalho. Rio de Janeiro: Editora Fiocruz; 2008.

8. World Health Organization. WHO global recommendations for the retention of health workers. http://www.who.int/hrh/migration/retention/en/ index.html (accessed on 19/Aug/2013).

9. Araújo E, Maeda A. How to recruit and retain health workers in rural and remote areas in developing countries: a guidance note. http://documents. worldbank.org/curated/en/2013/06/17872903/ recruit-retain-health-workers-rural-remote-areasdeveloping-countries (accessed on 19/Aug/2013).

10. Dal Poz MR, Mercer HS, Adams O, Stilwell B, Buchan J, Dreesch N, et al. Human resources for health: developing policy options for change In: Ferrinho P, Dal Poz M, editors. Towards a global health workforce strategy. Antwerp: ITGPress; 2003. p. 451-82. (Studies in Health Services Organisation \& Policy, 21).

Received 26/Aug/2013

Approved 27/Aug/2013 